\title{
Globalization Versus or Pro the State?
}

\author{
Alexandra Dobra
}

\section{Introduction}

\begin{abstract}
"State is the name of the coldest of all cold monsters. Coldly it tells lies, too; and this lie crawls out of its mouth: 'I, the state, am the people."'
\end{abstract}

(Nietzsche, 1985)

Saying that the State is in retreat implies to presuppose a relation of structural domination between globalization and the State. The question to ask is as following: is globalization the origin of the weakening of the State? Has the power of the State even weakened? In a rigorous sense, globalization is a structural and historical shift in power, "a process whereby state-centric agencies and terms of reference are dissolved in a structure of relations between different actors operating in a context which is truly global rather than merely international" (The Penguin Dictionary of International Relations, 1998: 201). Hence, globalization means multiple, overlapping and extensive interpenetration of national economies to the point where the importance of national and international networks declines relative to the weight of transnational and global networks. Yet there is a controversy over the extent to which globalization is merely an economic tendency or more. There is a controversy about the impact of globalization on policy choices and on the outcome of regulatory reforms.

Overall, globalization has been alleged to challenge domestic institutions. "Orthodoxies" argue that the State is in retreat and has entered into a new phase of abandonment (Hardt and Negri, 2001; Strange, 1997). "The essence of the State is that its sovereignty and its autonomous political organisation render it capable of delivering legitimacy inside a well defined territory. The international system $[\ldots]$ used to constitute a bastion of the State and the ultimate proof of its sovereignty and autonomy. The constant and increasing interpenetration has however the potential of transforming the international system into a system in which this external bastion is becoming eroded and finally undermined." On the other hand, "heterodoxies" argue that the process of globalization is suffering from exaggeration (Mann, 2001). What needs to be elucidated is if globalization is: (i) an all-encompassing and supreme phenomenon influencing States ad capite ad calcem or, (ii) function of the adaptability of States - of the differential capacity of these latter.

The present paper argues that the ut supra line of arguments share a common ground, namely the dichotomy between the political - State - and the economical - globalization. In order to palliate to this reductionist and mechanistic dichotomy, this paper will show that the State and globalization constitute a dyad.

\section{| The “Orthodox" Interpretation: Globalization Versus The State}

According to Hardt and Negri, the world has entered a new phase in the abandonment of the concept of the State. They postulate that globalization is transforming governance to the extent to which "sovereignty has taken a new form, composed of a series of national and supranational organisms" (Hardt and Negri, 2001 : xiii). Hence, a new form of sovereignty has occurred: the emergence of the empire, characterized by the absence of a territorial centre of power and characterized by a decentred apparatus of rule. In other words, empire is an order that suspends 
history, it is an order fixing an existing state of affairs for the whole eternity, which in Fukuyama`s terminology corresponds to the end of History.

Under globalization what has been weakened is the very autonomy and sovereignty of States via international and transnational organisations and institutions. Indeed, ranging from monolithic economic institutions defined under the Bretton Woods accords (International Monetary Fund; World Bank) to the recent juridical institutions (International Criminal Court), States seem at least a prima facie, to be both, under the umbrella of a global governance and embedded into a complex interdependence. Following Shaw, the global State provides a structure where the juridical sovereignty of nation-States is undermined (Shaw, 2000). An authoritative framework consisting of the dominance by a single set of new forms of institutions governing the various State centres has been created. There is a shift between the idea that the State is in principle able to determine itself and its future agenda and the global economy, the international organizations, the global and regional institutions, the international right and the military alliances which form an ensemble and which shape and reduce the options available to individual nationStates (Held, 1995).

The deficit of the State is made visible through three theses: (i) there is a structural deficit of the control by the State over its territory (e.g.: transnational fluxes of money; immigration); (ii) there is a crisis of legitimacy due to the incapacity of the State to define its future in a sovereign manner; (iii) a global governance system compensates the impotence of States, that enables a transfer of sovereignty aggravating the crisis of the State. Succinctly, the nation-State at term will get replaced by cosmopolitan structures of governance (Beck, 2006). However, it must be noticed that the dialectic of risks (environmental, security) which strengthens the crisis of the Sate is at the same time providing the means for going beyond it.

Succinctly, the State as a welfare State is in retreat, on account of the rapidly shifting economy, driven by markets, and having real consequences on the lives of individuals. The velocity of social, economic and technological changes as well as the shifting of ownership in the forms of mergers and take-overs results in unpredictable relationships and makes the State move towards assuming the role of a merely economic planner, instead of being a monitoring entity and an apparatus serving as a device for service delivery.

However, where the shoe pinches is that the "orthodox" interpretation ignores the variation of globalization in its multidimensionality and multidirectionality. Globalization has accompanied profound transitions and acts in dissimilar manners according to the concerned State. Globalization has not achieved to impose a new paradigm, a new doxa and praxis in a homogenous and self-governed way/autonomous.

\section{The “Heterodox" Interpretation : Globalization Pro The State}

In a "heterodox" interpretation, globalization is a mere exaggeration and corresponds to a semantic construction explaining the retreat of the State. Indeed, first of all, it is not the State per se which has weakened (e.g.: the State as a sovereign power) but one specific historical form of the State: the welfare State. Second, even the retreat of the welfare State is the product of post-industrial endogenous processes, which are as follows: (i) growth of service affecting welfare provisions and; (ii) expansion of governmental commitments (e.g.: negative impact of population aging) (Mishra, 1999). Furthermore, at a geographical level, contemporary capitalism is more transnational than global, since it operates exclusively in three regions, called "the core": Europe, North America and East Asia. Globalization is thus helping to create a trilateral order based on the nation-State system.

The very notion of globalization is thus problematized - since the economy today is more international than global - because nation-States have still significance in terms of maintaining domestic economies and economic relations beyond national boundaries. The role of the nation-State's vis-à-vis the global economy is characterized by an embedded autonomy.

Globalization and the State are social phenomena. Both phenomena are instituting and incorporating within the social structure norms - nomos. Globalization cannot be set into an autarkic system. Globalization cannot work without the State on account of the fact that there is a relational framework, a dyadic structure existing between globalization and the State. Based on the syntaxical structure of Clausewitz's sentence - "the State is the continuation of war by other means" - we can infer that the State is the continuation of globalization at the national level and vice-versa. The State is the depositary of a normative and economic legitimization of globalization. The State through its form of expression and application has been transformed by having been shifted from an overarching 
authoritarian figure to a more flexible and fluid structuration under globalization.

Globalization offers thus a general frame into which States are the main actors. However, the advent of globalization rests on the precondition of the existence of powerful States. Hence globalization, does not just provide a skeleton and arena for States, it is itself an actor. Both the State and globalization are legitimizing each other and each of them contains the preconditions of their mutual existence. It is usually thought that globalization is a purely economic phenomenon, however since it imposes norms and is itself constituted by the norms of the State, then it follows that it corresponds to an inherently political phenomenon as well.

There is no ubi maior minor cessat between globalization and the State. In the dyad globalization - State, both variables are independent and dependent at the same time. The State did not fade away, but the dynamic and forms of expression of the State have been transformed. The integrational model of the State prevailing ante 1990 has shifted towards a competition model. If globalization is more broadly understood as aiming to install a model having universalistic foundations, then it is not surprising that the State is no longer the first instance creating identity and defending categorical interests. Indeed, the individual has become increasingly multidimensional and thus his propensity to recognize himself in collectives of defence of categorial interests is declining. The individual has acquired a pluridimensional identity on account of the many objective and subjective determinants of memberships. More specifically, it can be argued that because systems of differentiation inside our societies tend to evanesce, the State and the democratic system entered into a new crisis. However, it is not a crisis per se, rather the State calls for an updated form of democracy, able to cope with the societal and global transformations. Succinctly, the relationship between the nation-State and the global context is a mutual one, on account that State policies are also involved in the international division of labour.

\section{Conclusion}

"Globalization has not ended the rise and rise of nation-States."

(Mann, 2001)

To conclude, globalization has provoked changes to the State. Globalization is mainly incarnated within neoliberalism and has accentuated democratic lacunas, because monitoring capacities in the field of democratic norms and institutional implementations have not been provided. Therefore, the democratic quality of the State has been weakened and limited (Weyland, 2004). Neoliberalism has not consolidated the Marshallian sequence of democracy - civil, political, social rights - and on this basis has occasioned a democratic deconsolidation. To this extent, globalization accounts for a retreat of the State as a democratic builder and universal welfare provider of services. However, it must be kept in mind that globalization is not static and neither exogenous. Globalization and the State are forming a dyad without which, one could not exist without the other. Globalization is the alter of the State and vice-versa. There is no pyramidal relation of authority between globalization and the State. Some trends strengthen both nation-States and transnationalism and hence, globalization has differential impacts on the different States in different regions.

\section{References}

Beck U. (2006) Cosmopolitan Vision, Cambridge: Polity Press.

Evans, G. (1998). The Penguin Dictionary of International Relations. London: Penguin.

Hardt, M. and Negri, A. (2001). Empire. Cambridge: Harvard University Press.
Held D. (1995) Democracy and the global order, Cambridge: Polity Press.

Mann, M., E. (2001).

Mishra, R. (1999). Globalization and the Welfare State. Edward Elgar Publishing: Cambridge University Press. 
Nietzsche, F., (1985). Ainsi parlait Zarahustra. Paris: Gallimard, Folio.

Strange, S. (1997). Casino Capitalism. Manchester : Manchester University Press.

Weyland, K., (2004). "Democracy and the new market model in Latin America."Latin American Politics \& Society 46 (1). 